\title{
EKSISTENSI DAN PROBLEMATIKA CALON INDEPENDEN DALAM PEMILUKADA DITINJAU DARI PERSPEKTIF UNDANG-UNDANG NOMOR 8 TAHUN 2015
}

\author{
Agus Budi Santoso \\ Staf Pengajar Program Studi Hukum Universitas Muhammadiyah Purworejo \\ Korespondensi: agus_budi.santoso.co.id
}

\begin{abstract}
Abstrak
Pemilihan Kepala Daerah di Indonesia mengalami perubahan yang cukup beragam, mulai dari pilkada secara langsung, pilkada melalui mekanisme perwakilan, yaitu dipilih oleh DPRD, hingga kembali pada pilkada secara langsung. Peraturan perundang-undangan mengenai pemilihan kepala daerah yang berlaku saat ini yaitu Undang-Undang Nomor 8 Tahun 2015 membuka peluang munculnya calon kepala daerah melalui jalur independen. Penelitian ini dalam rangka mengetahui dan menganalisis eksistensi dan permasalahan pencalonan Kepala Daerah secara independen dalam Pemilukada. Jenis penelitian yang digunakan merupakan penelitian hukum dengan pendekatan perundang-undangan, pendekatan konsep dan pendekatan kasus. Sumber bahan hukum dalam penelitian ini terdiri dari: primer, sekunder dan tersier. Teknik pengumpulan bahan hukum merupakan teknik studi kepustakaan dilengkapi dengan wawancara dengan responden terbatas yang relevan. Teknik analisis yang digunakan dalam penelitian ini adalah analisis deskripsi yuridis, yaitu analisis yang mendasarkan pada teori-teori, konsep dan peraturan perundang-undangan.
\end{abstract}

\section{Kata Kunci: Pemilihan Kepala Daerah; Calon Perseorangan.}

\begin{abstract}
The system of electing local leaders in Indonesia has changed varyingly, starting from direct election, the election through mechanisms of representatives in which the leader was elected by parliament, to the re-application of direct election. The Law No. 8 of 2015 which now governs local elections provides a chance for independent candidate to run for the local leadership office. This study was conducted to determine and analyze the existing problems surrounding the independent candidacy system in the local leader election. This research is basically a legal research utilizing statute approach, conceptual approach as well as case approach. Primary, secondary and tertiary legal materials are thorrughly used in this research. The legal materials are gathered through literature study and supplemented by interviews with limited relevant respondents. The analysis technique adopted in this research is juridical descriptive which is based on relevant theories, concepts and legislations.
\end{abstract}

Keywords: Regional Leader Elections; Independent Candidate. 


\section{PENDAHULUAN}

Pasal 1 ayat (2) Undang-Undang Dasar Negara Republik Indonesia Tahun 1945 (selanjutnya disebut UUD NRI 1945) menegaskan bahwa, "Kedaulatan berada di tangan rakyat dan dilaksanakan menurut Undang-Undang Dasar 1945". Salah satu perwujudan instrumen demokrasi tersebut adalah Pemilihan Kepala Daerah (Pilkada) yang selanjutnya menjadi Pemilihan Umum Kepala Daerah (Pemilukada).

Pengaturan Pemilukada di Indonesia selama ini masuk sebagai substansi Undang-Undang Pemerintahan Daerah, mulai dari Undang-Undang Nomor 22 Tahun 1999 tentang Pemerintahan Daerah, yang selanjutnya dicabut dengan Undang-Undang Nomor 32 Tahun 2004 dan perubahannya yaitu Undang-Undang Nomor 12 Tahun 2008. Selanjutnya Undang-Undang Pemerintahan Daerah tersebut dipecah menjadi 3 (tiga) Undang-Undang yaitu Undang-Undang tentang Pemerintahan Daerah, Undang-Undang tentang Desa dan Undang-Undang tentang Pemilukada. Dengan pemecahan Undang-Undang Pemerintahan Daerah tersebut akan memberikan ruang pengaturan yang lebih rinci dan komprehensif dari masing-masing isu sehingga memberikan kontribusi pada kelancaran jalannya roda pemerintahan daerah secara keseluruhan. ${ }^{1}$
Implementasi dari pembagian Undang-Undang tersebut, kemudian terbit Undang-Undang Nomor 22 Tahun 2014 tentang Pemilihan Gubernur, Bupati dan Walikota yang kemudian dikarenakan polemik mekanisme pemilihan, akhirnya dianulir oleh Presiden dengan menerbitkan Peraturan Pemerintah Pengganti UndangUndang (Perppu) Nomor 1 Tahun 2014 tentang Pemilihan Gubernur, Bupati dan Walikota. Permasalahan mendasar yang menjadi diskursus pengaturan adalah terkait mekanisme Pemilukada apakah secara langsung atau tidak langsung. Perppu ini kemudian disahkan DPR menjadi Undang-Undang Nomor 1 Tahun 2015, dengan catatan agar dilakukan revisi setelah resmi disahkan menjadi undang-undang. ${ }^{2}$ Oleh karena itu Undang-Undang Nomor 1 Tahun 2015 kemudian diubah menjadi Undang-Undang Nomor 8 Tahun 2015 dan terakhir diubah dengan Undang-Undang No. 10 Tahun 2016 tentang Perubahan Kedua Atas Undang-Undang Nomor 1 Tahun 2015 tentang Penetapan Peraturan Pemerintah Pengganti Undang-Undang (Perppu) Nomor 1 Tahun 2014 tentang Pemilihan Gubernur, Bupati dan Walikota menjadi Undang-Undang.

Pasal 1 angka 3 dan angka 4 Undang-Undang Pemilukada menyebutkan bahwa Calon Kepala Daerah (Gubernur, Bupati dan Walikota) dan

Gamawan Fauzi, 'Keterangan Pemerintah atas Rancangan Undang-Undang tentang Pemerintahan Daerah', (Rapat Kerja Pansus Rancangan Undang-Undang tentang Pemerintahan Daerah, Jakarta, April 2012)

2 A. Haryo Damardono dan Anita Yossihara, Kompas (Januari 2015). 
Calon Wakil Kepala Daerah (Wakil Gubernur, Wakil Bupati dan Wakil Walikota) adalah peserta Pemilihan yang diusulkan oleh partai politik, gabungan partai politik, atau perseorangan yang didaftarkan atau mendaftar di Komisi Pemilihan Umum (KPU) di daerah setempat.

Dalam Pasal 41 Undang-Undang No. 8 Tahun 2015, menyebutkan bahwa seseorang untuk dapat mendaftarkan diri sebagai calon kepala daerah dan Calon Wakil kepala daerah, harus memenuhi syarat, yaitu bahwa calon perseorangan dapat mendaftarkan diri sebagai calon Gubernur, Calon Bupati dan Calon Walikota serta Calon Wakil Gubernur, Calon Wakil Bupati dan Calon Walikota jika memenuhi syarat dukungan dengan ketentuan: bagi Provinsi, Kabupaten dan Kota dengan jumlah penduduk lebih dari 6.000.000 (enam juta) jiwa sampai dengan 12.000.000 (dua belas juta) jiwa harus didukung paling sedikit $7,5 \%$ ( tujuh setengah persen). Ketentuan ini berdasarkan putusan Mahkamah Konstitusi (MK) dalam Perkara Nomor 60/UndangUndang-XIII/2015 berubah menjadi hitungan persentase dukungan didasarkan atas jumlah penduduk yang telah mempunyai hak pilih sebagaimana dimuat dalam daftar calon pemilih tetap di daerah yang bersangkutan pada pemilihan umum sebelumnya (dikarenakan tidak semua penduduk mempunyai hak pilih).

Ketentuan Pasal 41 UndangUndang No 8 Tahun 2015 tersebut diatas selanjutnya telah diubah, yaitu dengan disahkannya Undang-Undang No. 10 Tahun 2016 tentang Perubahan Kedua Atas Undang-Undang Nomor 1 Tahun 2015 tentang Penetapan Peraturan Pemerintah Pengganti UndangUndang (Perppu) Nomor 1 Tahun 2014 tentang Pemilihan Gubernur, Bupati dan Walikota menjadi Undang-Undang.

Pasal 41 Undang-Undang No. 10 Tahun 2016 pada intinya mengatur persyaratan dukungan bagi Calon Perseorangan yang mendaftarkan diri sebagai Calon Gubernur dan wakil Gubernur, calon Bupati/Walikota dan Wakil Bupati/Walikota, didasarkan pada hitungan persentase dukungan yang didasarkan atas jumlah penduduk yang telah mempunyai hak pilih sebagaimana dimuat dalam daftar calon pemilih tetap di daerah yang bersangkutan pada pemilihan umum sebelumnya.

Data dari KPU dalam pemilukada serentak tahun 2015 menunjukan dari 20 pasangan calon gubernur dan wagub, 2 memilih jalur independen. Untuk calon bupati dan wakil bupati sejumlah 126 dari total 676 pasangan yang memilih maju perseorangan sedangkan untuk calon walikota 28 dari 144 pasangan. Data ini menunjukkan adanya peningkatan calon kepala daerah yang maju sebagai calon independen. Bahkan tidak sedikit pula calon independen yang meraih kemenangan di Pemilukada serentak 2015, seperti Walikota Bukit Tinggi, Bupati Kutai Kertanegara atau Walikota Bontang. 
Namun demikian, meskipun Pasal 41 Undang-Undang Pemilukada sebagai das sollen sudah mengatur dengan jelas calon kepala daerah dapat mengajukan pencalonan secara independen, tetapi untuk bisa memenangkan Pemilukada bagi calon independen tentu bukan persoalan yang mudah, karena dalam kenyataannya calon independen harus menghadapi beberapa persoalan (das sein). Persoalan-persoalan tersebut diantaranya tidak adannya mesin politik yang dapat menggalang dukungan masa, keterbatasan pendanaan dan kesulitan untuk mengatur keseimbangan kekuasaan dengan anggota Legislatif serta adanya anggapan calon independen melakukan deparpolisasi sebagaimana diungkapkan oleh Sekretaris DPD PDI-P DKI Jakarta, Prasetio Edi Marsudi menanggapi isu pencalonan Pemilukada DKI 2017.

Tulisan ini akan menganalisis eksistensi dan problematik pencalonan Kepala Daerah secara independen ditinjau dari Undang-Undang No. 8 Tahun 2015. Bagian pertama membahas pengaturan dan mekanisme Pencalonan Kepala Daerah Independen Ditinjau dari Perspektif UndangUndang Nomor 8 Tahun 2015. Fokus pembahasan ini adalah mekanisme dan persyaratan bagi calon kepala daerah dan calon wakil kepala daerah secara persorangan. Bagian kedua membahas problematika calon kepala daerah dan wakil kepala daerah Independen, yaitu kendala-kendala yang dihadapi calon kepala daerah dan wakil kepala daerah dari jalur Independen.

Sesuai dengan isu hukum yang ditujukan untuk mengkaji keberadaan dan problematika calon independen dalam Pemilukada dalam ranah UU No. 8 Tahun 2015, maka penelitian yang digunakan adalah penelitian hukum, yaitu suatu penelitian yang mengutamakan pengkajian terhadap ketentuan-ketentuan hukum positif maupun asas-asas hukum umum. Penelitian hukum normatif merupakan penelitian dengan mendasarkan pada bahan hukum baik primer maupun sekunder. ${ }^{3}$ Jenis pendekatan yang digunakan dalam penelitian ini adalah statute approach (pendekatan perundang-undangan), conceptual approach (pendekatan konsep) dan case approach (pendekatan kasus). ${ }^{4}$

Metode yang digunakan adalah analisis yuridis, yaitu analisis yang mendasarkan pada teori-teori, konsep dan peraturan perundang-undangan. Bahan hukum yang diperoleh disusun secara sistematis dan untuk selanjutnya analisis kualitatif dipakai untuk mencapai penjelasan yang dibahas. Hasil analisa tersebut kemudian dibahas dengan metode deduktif untuk mendapatkan pemahaman atas permasalahan sehingga dapat ditarik suatu kesimpulan yang dapat diper-

\footnotetext{
3 Soerjono Soekanto dan Sri Mamudji, Penelitian Hukum Normatif: Suatu Tinjauan Singkat (PT. Raja Grafindo Persada 1993) 13-14.

$4 \quad$ Peter Mahmud Marzuki, Penelitian Hukum (Kencana Prenada 2011) 93.
} 
tanggungjawabkan. Metode deduktif yang dimaksud merupakan suatu metode yang digunakan untuk mengambil kesimpulan dari pembahasan yang bersifat umum menjadi kesimpulan yang bersifat khusus sehingga jawaban atas permasalahan dalam penelitian ini dapat tercapai. ${ }^{5}$

\section{PEMBAHASAN}

Pengaturan dan Mekanisme Pencalonan Kepala Daerah Independen Ditinjau dari Perspektif Undang-Undang Nomor 8 Tahun 2015

Calon kepala daerah yang berangkat dari jalur independen sudah mulai muncul sejak tahun 2006 sebelum peraturan dari pemerintah ada. Hal ini menunjukkan adanya demokrasi di tingkat lokal terutama dalam pemilihan kepala daerah. Pemilukada selalu di dominasi oleh calon yang berasal dari partai politik. Hal ini membuat banyak pihak memberikan tuntutan terhadap lahirnya peraturan bagi calon independen. Salah satu wujud demokrasi adalah dengan adanya calon independen. Dukungan dari Undang-Undang menjadikan calon independen sebagai alternatif pilihan dalam pemilukada. Hal tersebut meningkatkan eksistensi dari calon independen.

Partisipasi politik pada masa sebelum reformasi merupakan barang langka. Puncak pemberangusan partisipasi politik adalah pada Orde Baru yang memandang politik identik dengan instabilitas sehingga peran partai politik diminimalisir, salah satunya dengan melakukan fusi partai politik hanya menjadi dua partai politik dan satu golongan, serta upaya menerapkan politik massa mengambang sehingga partai politik tidak dapat mengembangkan strukturnya ke struktur terkecil di masyarakat. ${ }^{6}$

Pada Orde Baru, sistem Pemilukada cenderung bersifat penunjukkan oleh Presiden atau Menteri Dalam Negeri, kepala daerah hanya berasal dari militer, birokrat, atau Golongan Karya. Pemerintah Pusat tidak memberikan ruang bagi calon kepala daerah dari partai politik apalagi dari individu di luar jalur militer, birokrat, atau Golongan Karya.

Pasca reformasi, ruang bagi individu untuk menjadi kepala daerah tetap tidak tersedia karena Undang-Undang Nomor 22 Tahun 1999 membatasi calon kepala daerah berasal dari partai politik. Partai politik yang mengalami euphoria mendominasi Pemilukada dengan mencalonkan kepala daerah melalui fraksi di DPRD untuk kemudian dipilih oleh DPRD secara langsung, bebas, dan rahasia, jujur, dan adil.

Undang-Undang Nomor 32 Tahun 2004 pun tidak memberikan ruang bagi calon perseorangan untuk ikut bersaing dalam Pemilukada karena masih menganut sistem pencalonan terbatas yang berpegang pada paradigma hanya partai politik yang me-

Ibid. 171 .

Bandingkan jumlah peserta Pemilu Tahun 1955 adalah sebanyak 172 partai politik, sedangkan pada Tahun 1977 dikerucutkan menjadi hanya 2 partai politik dan 1 golongan. 
miliki sumber daya manusia yang mumpuni dalam memimpin pemerintahan.

Undang-Undang Nomor 12 Tahun 2008 menjadi antithesis dari dominasi partai politik dalam Pemilukada dengan membuka pintu bagi calon perseorangan ikut serta dalam Pemilukada. Undang-Undang Nomor 12 Tahun 2008 sebenarnya merespon Putusan Mahkamah Konstitusi Nomor 5/ Pundang-Undang-V/2007, tanggal 23 Juli $2007^{7}$. Ranggalawe, anggota DPRD Kabupaten Lombok Tengah, mengajukan pengujian materiil terhadap Pasal 56 Ayat (2), Pasal 59 Ayat (1), Ayat (3), Ayat (4), Ayat (5) huruf a, Ayat (5) huruf c, Ayat (6) dan Pasal 60 ayat (2), Ayat (3), Ayat (4) dan Ayat (5) Undang-Undang Nomor 32 Tahun 2004. Lalu Ranggalawe berpandangan bahwa ketentuanketentuan tersebut bertentangan dengan Pasal 18 ayat (4), Pasal 27 ayat (1), Pasal 28 D ayat (1), Pasal 28 D ayat (3), dan Pasa 28 I ayat (2) UUD NRI 1945.

Permohonan tersebut dikabulkan oleh MK untuk sebagian, dimana dalam pertimbangannya turut menganalisis sistem Pemilukada di Provinsi Aceh berdasarkan Undang-Undang Nomor 11 Tahun 2006 tentang Pemerintahan Aceh yang lebih dahulu telah memberikan ruang bagi perseorangan ikut serta dalam Pemilukada. Menurut MK, kesempatan bagi calon perseorangan dalam Pemilukada di Provinsi Aceh diberikan untuk mencip- takan pelaksanaan Pemilukada yang demokratis. Sifat keistimewaan Provinsi Aceh tidak ada sangkut pautnya dengan perbedaan peserta Pemilukada sehingga sepatutnya seluruh daerah lain di luar Provinsi Aceh juga memberikan kesempatan kepada calon independen ikut serta dalam Pemilukada. Pasal 59 ayat (1) UndangUndang Nomor 32 Tahun 2004 sebagaimana diubah dengan UndangUndang Nomor 12 Tahun 2008 merumuskan peserta Pemilukada dan wakil kepala daerah berasal dari partai politik dan calon perseorangan. ${ }^{8}$

Keberadaan calon perseorangan dalam Pemilukada secara langsung memberikan peluang bagi kemunculan pimpinan yang berasal dari politik arus bawah. Masyarakat tidak sekedar menjadi penonton atau pemilih caloncalon yang diusulkan oleh partai politik namun dapat bertindak sebagai aktor politik yang secara aktif mengusung calon dan memilihnya di Pemilukada atau bahkan menjadi calon kepala daerah. Calon independen dapat dimaknai sebagai bentuk konkrit demokrasi partisipatoris yang dibangun oleh dan dalam masyarakat, kemudian menjadi contoh bagaimana demokrasi memberikan banyak pilihan calon pemimpin bagi masyarakat sekaligus menjawab kegelisahan masyarakat terhadap kredibilitas partai politik.

Keran demokrasi yang dibuka luas berimplikasi pada berdirinya banyak partai politik namun kuantitas partai 
politik ini tidak diiringi dengan kualitas kader partai politik. Secara empiris partai politik dapat dikatakan gagal dalam menjalankan salah satu fungsinya yaitu kaderisasi yang seharusnya menjadi calon pemimpin dalam skala lokal dan nasional dalam mengisi jabatan-jabatan publik. ${ }^{9}$ Padahal jika mengacu Pasal 11 Undang-Undang Nomor 2 Tahun 2008 tentang Partai Politik sebagaimana telah diubah dengan Undang-Undang Nomor 2 Tahun 2011, fungsi partai politik yang diwujudkan secara konstitusional adalah:

a. memberikan pendidikan politik baik bagi anggotanya maupun masyarakat luas;

b. menciptakan iklim yang kondusif bagi persatuan dan kesatuan bangsa Indonesia untuk kesejahteraan masyarakat;

c. menyerap, menghimpun, dan menyalurkan aspirasi politik masyarakat dalam merumuskan dan menetapkan kebijakan negara;

d. sebagai sarana partisipasi politik warga negara;

e. sebagai instrumen rekrutmen politik.

Kepercayaan masyarakat mengalami degradasi akibat proses Pemilukada sarat dengan transaksi politik.
Penilaian terhadap calon yang diusung oleh partai politik bukan berdasarkan kemampuan dan kualitas tetapi atas dasar keuntungan/janji yang ditawarkan oleh calon kepada partai politik sehingga merusak keobjektivitasan partai politik dalam mengusulkan calonnya.

Transaksi semacam ini menimbulkan politic cost, misalnya saat seseorang ingin dicalonkan sebagai kepala daerah oleh partai politik tertentu, calon tersebut harus menyetorkan dana kepada partai pengusung, selain dari janji politik yang diberikan jika berhasil menduduki kursi kepala daerah sehingga menimbulkan keterikatan dengan partai politik pengusung ketika membuat kebijakan. Selain itu, calon kepala daerah meminta dukungan dana kepada pengusaha karena biaya kampanye yang tinggi. Hubungan ini mengikat kepala daerah terpilih dengan kepentingan-kepentingan pengusaha pendukung sehingga kepala daerah tidak lagi menempatkan kepentingan rakyat sebagai prioritas. ${ }^{10}$ Uang merupakan salah satu faktor yang mempengaruhi hasil kompetisi politik. ${ }^{11}$ Banyak politisi bahkan menghalalkan segala cara untuk mengumpulkan dana kampanye, seperti korupsi. ${ }^{12}$ Pada akhirnya praktik demikian

$9 \quad$ Miriam Budiardjo, Dasar-Dasar Ilmu Politik (Gramedia Pustaka Umum 2010) 408.

10 Berdasarkan laporan dana kampanye peserta Pemilukada Provinsi DKI Jakarta kepada KPU, total pengeluaran kampanye sekitar 106 milyar rupiah. Lihat Didik Supriyanto dan Lia Wulandari, Basa-Basi Dana Kampanye (Perludem 2013), 167-168. Mengenai dampak politik uang juga dapat dilihat pada Didik Suhariyanto, 'Dampak Money Politics Hasil pemilu Kepala Daerah terhadap Konstitusi dan Kebijakan Pemerintah Daerah' (2010) 7 Jurnal Ilmiah Progresif 1, 1-3.

11 Ibrahim Z. Fahmi Badoh dan Abdullah Dahlan, Korupsi Pemilu di Indonesia (Indonesian Corruption Watch dan Yayasan TIFA 2010) 32-33.

12 Hamdan Zoelva, 'Memberantas Electoral Corruption' (2013) 5 Jurnal Pemilu dan Demokrasi 1,3 \& 5. 
memunculkan kehidupan partai politik yang bersifat oligarkis, elitis dan personalistis. ${ }^{13}$ Ibrahim Zuhdy menyatakan politic cost berdampak pada pemerintah yang berkuasa jika donator dana kampanye memberikan dukungan sebagai investasi politik bagi kepentingan mereka. ${ }^{14}$

Undang-Undang Nomor 22 Tahun 2014 memberikan perubahan signifikan terhadap sistem Pemilukada namun tetap menyediakan ruang bagi calon independen dalam Pemilukada. Persyaratan dukungan yang harus dipenuhi oleh calon kepala daerah pun tidak ada perubahan sama sekali. Namun, keberadaan calon independen ini menjadi sangat kontras dengan sistem Pemilukada keterwakilan. Pada Pemilukada secara langsung, calon kepala daerah melalui calon independen harus melengkapi persyaratan jumlah dukungan minimal yang dibuktikan dengan fotocopy Kartu Tanda Penduduk (KTP) pendukung agar dapat masuk dalam daftar calon kepala daerah. Pada Pemilukada secara langsung, masyarakat daerah bersangkutan memilih calon kepala daerah tersebut secara langsung (one man one vote). Melalui mekanisme pemilihan tersebut, masyarakat pendukung calon kepala daerah dari calon perseorangan memiliki peluang untuk memilih kembali calon dukungannya.

Keberadaan calon perseorangan menjadi timpang jika dilakukan me- lalui Pemilukada keterwakilan, yaitu dipilih oleh DPRD. Calon kepala daerah dari partai politik memiliki dukungan partai dalam bentuk fraksi di DPRD namun calon kepala daerah dari calon perseorangan tidak memiliki dukungan di DPRD karena kekuatan dukungan mereka terletak pada masyarakat langsung. DPRD memang merupakan lembaga perwakilan yang sudah menjadi tugasnya mewakili masyarakat, khususnya konstituennya, di pemerintahan namun dalam menjalankan tugas dan fungsinya kesempatan bagi DPRD untuk tidak memenuhi aspirasi masyarakat pun cukup besar, terutama dalam hal Pemilukada.

Pemilukada melalui mekanisme keterwakilan rentan terjadi pelanggaran terhadap hak asasi masyarakat, khususnya hak untuk ikut serta dalam pemerintahan. Secara garis besar, dalam Pemilukada melalui sistem keterwakilan terdapat dua tahapan, yaitu mengumpulkan dukungan minimal dan pemilihan itu sendiri, dimana subjek pemilih pada kedua tahapan tersebut berbeda, baik dari sisi jumlah maupun kepentingannya. Tidak dapat dipungkiri, anggota DPRD selain mewakili konstituennya juga turut mewakili partai politiknya di pemerintahan. Jika kedua pihak tersebut memiliki aspirasi yang berbeda maka anggota DPRD harus dapat memilih pihak yang diprioritaskan. Meskipun

\footnotetext{
13 Didik Supriyanto dan Lia Wulandari, Bantuan Keuangan Partai Politik: Metode Penetapan Besaran, Transparansi dan Akuntabilitas Pengelolaan (Perludem 2012) 1 \& 3.

14 Ibrahim Zuhdhy Fahmi Badoh, Kajian Potensi-Potensi Korupsi Pemilukada (ICW 2010) 4-6.
} 
anggota DPRD memilih memprioritaskan aspirasi konstituennya, anggota DPRD tidak dapat memenuhi seluruh aspirasi tersebut.

Pada Pemilukada keterwakilan, jika setiap anggota DPRD memiliki 100.000 konstituen dengan pilihan calon kepala daerah yang beragam, yang bersangkutan tidak dapat menyalurkan aspirasi tersebut dengan memilih beragam calon kepala daerah. Berbeda jika Pemilukada dilakukan secara langsung (one man one vote), masyarakat dapat memilih sendiri calon kepala daerahnya tanpa terhalang oleh sistem yang berlaku.

Sejak perubahan Undang-Undang Nomor 32 Tahun 2004 melalui UndangUndang Nomor 12 Tahun 2008, sistem Pemilukada telah mengalami dua kali perubahan, yaitu melalui UndangUndang Nomor 22 Tahun 2014 yang mengatur sistem Pemilukada secara perwakilan yang segera dianulir oleh Presiden melalui PERPPU Nomor 1 Tahun 2014 dan telah disahkan menjadi undang-undang pada tanggal 20 Januari 2014 yang mengembalikan sistem Pemilukada secara langsung. Seluruh peraturan tersebut tetap menyediakan ruang bagi calon independen dalam pemilukada. Tidak adanya perubahan mengenai ketentuan persyaratan jumlah dukungan minimal bagi calon perseorangan menunjukkan selama proses pembentukkan Undang-Undang maupun PERPPU, baik DPR maupun Presiden tidak menyadari atau tidak mau menyadari adanya beban persyaratan jumlah dukungan calon perseorangan yang tidak memiliki kekuatan pengumpul massa sebagaimana partai politik.

Perbedaan mendasar mengenai jumlah dukungan minimal calon kepala daerah adalah dalam hal acuan jumlah persentase dukungan minimal calon perseorangan yang menggunakan jumlah penduduk dalam suatu provinsi/kabupaten/kota, sedangkan partai politik untuk dapat mencalonkan kepala daerah harus memenuhi syarat perolehan sebesar 20\% (dua puluh persen) dari jumlah kursi DPRD atau sebesar 25\% (dua puluh lima persen) dari jumlah perolehan suara sah dalam pemilihan legislatif di daerah bersangkutan. Partai politik yang mencalonkan kepala daerah, acuan dukungan minimalnya menggunakan jumlah penduduk yang memiliki hak pilih dan dikerucutkan lagi menjadi penduduk yang menggunakan hak pilihnya dan dinyatakan sebagai suara yang sah. Untuk mencapai suatu tujuan yang sama, yaitu menjadi calon kepala daerah, UndangUndang justru menggunakan dua acuan perhitungan yang berbeda, yaitu jumlah penduduk, dalam hal ini penduduk yang tidak dan/atau belum memiliki hak pilih tetap dihitung, dan jumlah perolehan suara sah dalam pemilihan legislatif.

Calon perseorangan berasal dari masyarakat tanpa dukungan kendaraan politik apapun, berbeda dengan calon kepala daerah yang diusulkan oleh partai politik. Beban pengumpulan jumlah dukungan minimal calon 
independen harus dihadapi sendiri, sedangkan partai politik bekerja meraih dukungan minimal secara sistematis melalui organisasi partai maupun oleh calon legislatif sejak pemilihan umum legislatif.

Undang-Undang telah menjawab amanat pemenuhan HAM dari UUD NRI 1945 dengan menyediakan akses bagi calon perseorangan untuk terlibat dalam Pemilukada namun melalui Undang-Undang pula masyarakat dihambat untuk terlibat karena persyaratan yang membebani dan cenderung tidak berimbang dengan calon kepala daerah dari partai politik. Pembentuk Undang-Undang terkesan setengah hati dalam membuka pintu bagi calon independen untuk terlibat dalam Pemilukada. Pada Pemilukada Kabupaten Garut Tahun 2008 memang dimenangkan oleh pasangan calon perseorangan, Aceng Fikri dan Dicky Chandra, ${ }^{15}$ namun sebenarnya perlu dikaji kembali syarat jumlah dukungan minimal yang harus dipenuhi oleh calon independen terutama jika dipandang dari perspektif HAM.

Pasal 28 D ayat (3) UUD NRI 1945 dengan jelas mengamanatkan persamaan kesempatan kepada setiap warga negara dalam pemerintahan. Prinsip persamaan ini harus dimaknai tanpa diskriminasi, dimana persyaratan untuk terlibat dalam pemerintahan harus berlaku sama terhadap semua orang. ${ }^{16}$ Hak warga negara untuk mendapatkan kesempatan yang sama dalam pemerintahan pun dirumuskan dalam Pasal 24 International Covenant on Civil and Political Rights, yaitu:

"Every citizen shal have the right and the opportunity, without any of the distinctions mentioned in article 2 and without unreasonable restrictions:

(a) To take part in the conduct of public affairs, directly or through freely chosen representatives;

(b) To vote and to be elected at genuine periodic elections which shall be by universal and equal suffrage and shall be held by secret ballot, guaranteeing the free expression of the will of the electors;

Kovenan tersebut telah diratifikasi oleh pemerintah melalui UndangUndang Nomor 12 Tahun 2005 tentang Pengesahan International Covenant on Civil and Political Rights (Kovenan Internasional tentang Hak-Hak Sipil dan Politik), sehingga sebagai negara yang telah meratifikasi Indonesia memiliki kewajiban untuk melaksanakan substansi kovenan tersebut.

Ketimpangan acuan jumlah persentase antara calon kepala daerah dari partai politik dan calon perseorangan menunjukkan bahwa kesem-

$15 \quad$ Pada Pemilukada Kabupaten Garut Tahun 2008 diikuti oleh 13 pasangan calon kepala derah dan wakil kepala daerah. Tiga dari pasangan calon tersebut berasal dari calon perseorangan dan berhasil dimenangkan oleh pasangan calon Aceng Fikri dan Dicky Chandra yang merupakan Pengusaha dan Artis. Dua pasangan dari calon perseorangan adalah Abdul Halim dan Nandang Suhendra (Ulama dan Direktur Program BPPT) serta Sali Iskandar dan Asep Kurnia Hamdani (Pengusaha dan Kepala Desa Sukakarya). Lihat KPU Kab. Garut, Kilas Balik Pemilu Bupati \& Wakil Bupati Garut Tahun 2008, (KPU Garut, 2012), 50,75. Lihat Lia Wulandari, Politik Biaya Tinggi dalam Pemilihan Kepala Daerah, (Perludem, 2014), 13

16 Janedjri M. Gaffar, 'Peran Putusan Mahkamah Konstitusi dalam Perlindungan Hak Asasi Manusia terkait Penyelenggaraan Pemilu' (2013)10 Jurnal Konstitusi 1, 18-19 
patan untuk terlibat dalam pemerintahan belum sama karena peluang bagi partai politik mengusulkan calon kepala daerah lebih besar dibandingkan calon perseorangan. Pemerintah sebagai pelaku utama dalam penegakan HAM seharusnya mampu menjembatani hal tersebut.

Undang-Undang telah memberikan ruang bagi calon perseorangan untuk terlibat dalam Pemilukada namun melalui Undang-Undang pula calon perseorangan dibebani persyaratan yang tidak seimbang dengan persyaratan bagi calon kepala daerah dari partai. Beban tersebut akan semakin bertambah apabila pemerintah mengubah mekanisme Pemilukada menjadi secara perwakilan melalui DPRD. Seymour Martin Lipset, sosiolog Amerika Serikat, menyampaikan bahwa hak demokrasi tidak boleh dibatasi oleh apapun karena pembatasan tersebut merupakan suatu pengkhianatan dalam demokrasi sehingga warga negara harus diperhadapkan pada kesempatan yang sama dalam persaingan memperoleh jabatan politik dan pemerintahan. ${ }^{17}$

MK dalam pertimbangan hukumnya menyatakan persyaratan jumlah dukungan bagi calon perseorangan tidak boleh lebih berat ataupun lebih ringan dari syarat partai politik untuk dapat mengusulkan calon kepala daerah, hal ini untuk menjaga agar tidak terjadi ketidakadilan maupun menjaga Pemilukada tidak diisi oleh calon yang tidak bersungguh-sungguh sehingga dapat menciderai nilai maupun citra demokrasi. Keberadaan calon perseorangan dalam Pemilukada sebaiknya diikuti dengan aturan pelaksanaan yang setara antara calon perseorangan dan calon dari partai politik. Ketimpangan syarat antara keduanya akan menimbulkan ketidakadilan sehingga tujuan keberadaan calon independen dalam Pemilukada, yaitu memberikan ruang bagi masyarakat untuk terlibat langsung dalam Pemilukada tidak tercapai. Amanat UUD NRI 1945 untuk memberikan perlindungan terhadap hak asasi warga negaranya, khususnya hak untuk ikut serta dalam pemerintahan dengan kesempatan yang sama belum dilaksanakan sepenuhnya oleh pemerintah.

Eksistensi calon independen dalam Pemilukada melalui pengaturan dan mekanisme pencalonan Kepala Daerah secara independen ditinjau dari perspektif Undang-Undang Nomor 8 Tahun 2015 tidak meniadakan calon perseorangan namun juga tidak memberikan implikasi terhadap ketentuan bagi calon perseorangan. Tidak adanya perubahan mengenai persyaratan bagi calon perseorangan terutama syarat persentase jumlah dukungan minimal calon kepala daerah dan dasar acuan persentase jumlah dukungan antara calon perseorangan dan calon partai politik yang cenderung membebani calon perseorangan, menunjukkan

$17 \quad$ Disampaikan oleh Ahli Prof. Dr. Ibramsyah, M.S, dalam keterangan persidangan Mahkamah Konstitusi. Lihat Putusan MK Nomor 5/PUU-V/2007, tanggal 23 Juli 2007. 
pembentuk Undang-Undang belum secara total dan utuh memenuhi hak warga negara untuk ikut serta dalam pemerintahan. Ketentuan mengenai persyaratan calon kepala daerah hendaknya lebih mengedepankan perspektif HAM dengan memberikan ruang dan kesempatan yang sama kepada masyarakat, salah satunya dengan menghilangkan perbedaan dasar acuan persentase jumlah dukungan, yaitu dengan mengganti variabel jumlah penduduk dengan jumlah penduduk yang memiliki hak pilih, sebagaimana telah diatur dalam pasal 41 Undang-Undang No. 10 Tahun 2016.

\section{Problematika Calon Independen Dalam Pemilukada}

Calon independen yang tidak berasal dari parpol berarti bahwa ia tidak memiliki memiliki mesin politik untuk bisa mengakses pemilih. Padahal calon independen juga membutuhkan jaringan massa yang kuat. Tanpa dukungan jaringan massa, calon independen tidak memiliki jangkauan yang luas untuk bisa mempengaruhi massa ke lapisan masyarakat bawah. Selain itu calon independen juga memiliki keterbatasan dalam hal pendanaan mengingat bahwa biaya politik yang dibutuhkan dalam mengikuti pemilukada tentunya tidak sedikit dan harus ditanggung sendiri. Oleh sebab itu, calon independen sesungguhnya hanya memberi kesempatan kepada pemilik modal, pengusaha, para pejabat birokrasi sipil atau militer, atau tokoh masyarakat/agama yang memiliki dukungan finansial yang memadai. ${ }^{18}$

Problem lain yang dihadapi oleh calon independen adalah jika terpilih maka calon independen harus bisa mengatur keseimbangan kekuasaan dengan anggota legistatif karena sebagai konsekuensi calon independen tidak mempunyai dukungan politik dari partai politik, maka tentu akan kesulitan memperoleh dukungan politik di lembaga legistatif sehingga seringkali terjadi inkonsistensi sikap politik. Misalnya, untuk menjaga kesimbangan kekuasaan, kepala daerah kemudian masuk partai atau diberi tawaran untuk memimpin partai politik tertentu. Dalam kondisi demikian, kepala daerah yang awalnya calon independen menjadi kehilangan ideologinya karena akan memberikan dampak yang tidak menguntungkan terhadap keberlangsungan pemerintahan. ${ }^{19}$ Dengan demikian maka proses keberlangsungan pemerintahan akan tetap saja dikendalikan oleh kepentingan partai politik. Aceng Fikri merupakan salah satu contoh kepala daerah yang terpilih dari calon independen dan dalam pemerintahannya, ia mengalami kegagalan baik

18 Syarief Makhya, 'Calon Independen dan Kelangsungan Pemerintahan' < http:// fbandung.wordpress.com/selected-feature/calon-independen-dan-kelangsunganpemerintahan/> diakses 8 Juli 2016. 
dalam mempertahankan ideologinya maupun dalam mempertahankan keseimbangan kekuasaan dengan anggota legislatif sehingga berakhir dengan pemakzulan.

Berdasarkan uraian di atas, problematika yang dihadapi calon kepala daerah dan wakil kepala daerah yang berasal dari jalur independen dalam pemilukada sekalipun telah diatur didalam perundang-undangan untuk menjamin haknya, tetapi dalam mengikuti pemilukada kenyataannya menghadapi banyak problematika yaitu tidak memiliki mesin politik, menanggung sendiri biaya politik yang dibutuhkan, dan jika terpilih maka harus bisa mengatur keseimbangan kekuasaan dengan anggota legislative karena tidak memiliki dukungan politik di legislatif

\section{PENUTUP}

Pengaturan dan mekanisme pencalonan Kepala Daerah secara independen ditinjau dari perspektif UndangUndang Nomor 8 Tahun 2015 tidak meniadakan calon perseorangan namun tidak juga memberikan implikasi terhadap ketentuan bagi calon perseorangan. Tidak adanya perubahan mengenai persyaratan bagi calon perseorangan terutama syarat persentase jumlah dukungan minimal calon kepala daerah dan dasar acuan persentase jumlah dukungan, menunjukkan pembentuk undangundang belum secara total dan utuh memenuhi hak warga negara untuk ikut serta dalam pemerintahan dengan adanya perbedaan acuan persentase jumlah dukungan antara calon perseorangan dan calon partai politik yang cenderung membebani calon perseorangan. Ketentuan mengenai persyaratan calon kepala daerah hendaknya lebih mengedepankan perspektif HAM dengan memberikan ruang dan kesempatan yang sama kepada masyarakat, salah satunya dengan menghilangkan perbedaan dasar acuan persentase jumlah dukungan, yaitu dengan mengganti variabel jumlah penduduk dengan jumlah penduduk yang memiliki hak pilih sebagaimana telah diatur dalam Undang-Undang No. 10 Tahun 2016.

Calon kepala daerah dan wakil kepala daerah yang berasal dari jalur independen dalam pemilukada telah diatur didalam perundang-undangan untuk menjamin haknya, akan tetapi dalam kenyataannya menghadapi banyak problematika yaitu calon independen tidak memiliki mesin politik, menanggung sendiri biaya politik yang dibutuhkan, dan harus bisa mengatur keseimbangan kekuasaan dengan anggota legislatif karena tidak memiliki dukungan politik di legislatif.

\section{DAFTAR BACAAN}

\section{Buku}

Badoh, Ibrahim Z. Fahmi, dan Abdullah Dahlan, Korupsi Pemilu di Indonesia (Indonesian Corruption Watch dan Yayasan TIFA 2010). 
Badoh, Ibrahim Z. Fahmi, Kajian PotensiPotensi Korupsi Pemilukada (ICW 2010).

Budiardjo, Miriam, Dasar-dasar Ilmu Politik (Gramedia Pustaka Umum 2010).

Marzuki, Peter Mahmud, Penelitian Hukum (Kencana Prenada 2011).

Soekanto, Soerjono, dan Sri Mamudji, Penelitian Hukum Normatif: Suatu Tinjauan Singkat (PT Raja Grafindo Persada 1993).

Supriyanto, Didik, dan Lia Wulandari, Bantuan Keuangan Partai Politik: Metode Penetapan Besaran, Transparansi dan Akuntabilitas Pengelolaan (Perludem 2012). ,Basa-Basi Dana Kampanye (Perludem 2013).

Wulandari, Lia, Politik Biaya Tinggi dalam Pemilihan Kepala Daerah (Perludem 2014).

\section{Makalah/Jurnal}

Gaffar, Janedjri M., 'Peran Putusan Mahkamah Konstitusi dalam Perlindungan Hak Asasi Manusia terkait Penyelenggaraan Pemilu' (2013) 10 Jurnal Konstitusi 1.

Suhariyanto, Didik, 'Dampak Money Politics Hasil pemilu Kepala Daerah terhadap Konstitusi dan Kebijakan Pemerintah Daerah' (2010) 7 Jurnal Ilmiah Progresif 1.

\section{Peraturan Perundang-Undangan}

Undang-Undang Dasar Negara Republik Indonesia Tahun 1945.
Undang-Undang Negara Republik Indonesia Nomor 10 Tahun 2016 tentang Perubahan Kedua Atas Undang-Undang Nomor 1 Tahun 2015 tentang Penetapan Peraturan Pemerintah Pengganti UndangUndang (Perppu) Nomor 1 Tahun 2014 tentang Pemilihan Gubernur, Bupati dan Walikota menjadi Undang-Undang.

Undang-Undang Negara Republik Indonesia Nomor 8 Tahun 2015 tentang Pemilihan Gubernur, Bupati, dan Walikota.

Undang-Undang Negara Republik Indonesia Nomor 1 Tahun 2015 tentang Penetapan Peraturan Pemerintah Pengganti UndangUndang Negara Republik Indonesia Nomor 1 Tahun 2014 tentang Pemilihan Gubernur, Bupati, dan Walikota.

Undang-Undang Negara Republik Indonesia Nomor 22 Tahun 2014 tentang Pemilihan Gubernur, Bupati, dan Walikota.

Undang-Undang Negara Republik Indonesia Nomor 12 Tahun 2008 tentang Perubahan Kedua atas Undang-Undang Nomor 32 Tahun 2004 tentang Pemerintahan Daerah.

Undang-Undang Negara Republik Indonesia Nomor 32 Tahun 2004 tentang Pemerintahan Daerah.

Peraturan Pemerintah Pengganti Undang-Undang Negara Republik Indonesia Nomor 1 Tahun 2014 tentang Pemilihan Gubernur, Bupati, dan Walikota. 